\title{
CHARAKTERYSTYKA SYNTAKTYCZNA PLIKÓW POMOCY UKRAIŃSKIEJ WERSJI PAKIETU MICROSOFT OFFICE
}

\author{
PRZEMYSŁAW JÓŹWIKIEWICZ \\ Uniwersytet Wrocławski, Wrocław — Polska \\ СИНТАКСИЧНА ХАРАКТЕРИСТИКА ФАЙЛІВ \\ ДОВІДКИ УКРАЇНОМОВНОГО ВАРІАНТУ \\ ОФIСНОГО ПАКЕТУ MICROSOFT OFFICE \\ ПШЕМИСЛАВ ЮЗВІКЕВИЧ \\ Вроцлавський університет, Вроцлав - Польща
}

АНОТАЦІЯ. У статті описано синтаксичну структуру файлів довідки україномовного варіанта офісного пакету Microsoft Office. Виявлено, що центрами речень $є$ насамперед предикативи на зразок можна, потрібно, слід, а також модальні дієслівні присудки, безособові форми на -но, -то, зокрема і їхні варіанти (було ввімкнено, має бути встановлено, повинно бути обладнано і под.); простежуємо також активність обставинних речень мети та умови. Файли довідки містять велику кількість багатокомпонентних складних речень (передусім і з дієсловами наказового способу) і питальні речення та структури з репрезентантами ввічливості.

\section{THE SYNTACTIC STRUCTURE OF HELP FILES \\ OF THE UKRAINIAN VERSION OF MICROSOFT OFFICE SOFTWARE}

\author{
PRZEMYSŁAW JÓŹWIKIEWICZ \\ University of Wroclaw, Wroclaw — Poland
}

\begin{abstract}
The paper presents the syntactic structure of help files of the Ukrainian version of Microsoft Office software. The sentence centres are usually predicate words можна, потрібно, слід, modal predicates, impersonal constructions -но, -то, including their complex forms (було ввімкнено, має бути установлено, повинно бути обладнано); very frequent are clauses of purpose and conditional clauses. Help files are also characterised by a magnitude of compound-complex sentences (also including the imperative forms), questions and structures which contain salutations.
\end{abstract}

$\mathrm{J}$

ednym z dwóch (obok serii systemów operacyjnych Windows) flagowych produktów korporacji Microsoft jest linia aplikacji biurowych Microsoft Office. Choć pierwszą wersję tego oprogramowania dedykowaną na platformę Windows wydano już w sierpniu 1992 r., to produkt przeznaczony dla odbiorcy ukraińskiego pojawił się dopiero dekadę później. 12 marca 2002 roku premierę miały oficjalne ukraińskojęzyczne nakładki dla programów MS Word 2002 i MS Outlook 2002 będące częścią pakietów MS Office XP Professional i MS Office XP Small Business. Na początku 2004 r., a więc kilka miesięcy po swej światowej premierze, ukazała się ukraińska wersja pakietu $M S$ Office $2003^{1}$, natomiast kolejne wydania produktów biurowych

${ }^{1}$ Ukraińskojęzyczną nakładkę LIP (ang. Language Interface Pack) należało zainstalować na rosyjskojęzycznej platformie systemu. 
koncernu (MSO 2007, MSO 2010, MSO 365, MSO 2013) były już ukrainizowane w miarę na bieżąco ${ }^{2}$. Poziom ukrainizacji wersji tekstowej wspomnianych produktów jest wyraźnie zróżnicowany — od pełnych błędów, w wysokim stopniu zrusyfikowanych pierwszych ukraińskojęzycznych opracowań produktu, po dobre w niemal każdym aspekcie językowym najnowsze wersje oprogramowania.

Naturalnie i one nie są pozbawione usterek, jednakże to nie kwestia poprawności przekładu warstwy tekstowej oprogramowania serii Microsoft Office na język ukraiński jest przedmiotem rozważań w niniejszym artykule.

Celem proponowanego opracowania jest prezentacja najbardziej charakterystycznych dla ukraińskojęzycznych plików pomocy ${ }^{3}$ pakietu Office konstrukcji składniowych, struktur występujących częściej niż inne, stanowiących niejako ich znak rozpoznawczy.

Opisywane źródło nie jest nazbyt „eksploatowane” przez językoznawców. Nieliczne opracowania dotyczą głównie zagadnień związanych z procesem przekładu na język ukraiński poszczególnych struktur czy weryfikacji ich poprawności językowej ${ }^{4}$ — autorzy rzadko skupiają się na problematyce stricte składniowej ${ }^{5}$.

Wypada zaznaczyć, iż struktura składniowa tekstów z dziedziny informatyki (a do nich zaliczają się przecież teksty plików pomocy pakietu Office) jest znacznie zróżnicowana. Warunkiem decydującym jest tu źródło, z którego badany tekst się wywodzi. Inne bowiem w swej budowie będą komunikaty okien dialogowych, inne wskazówki zawarte w „helpach”, jeszcze inne informacje umieszczane w podręcznikach do informatyki czy tzw. „,bibliach” użytkownika. Wspólnym mianownikiem dla nich wszystkich jest słownictwo informatyczne.

Pomijając teksty naukowe z dziedziny informatyki, których w języku ukraińskim jest stosunkowo niewiele (odznaczające się wszystkimi cechami charakterystycznymi dla tego właśnie rodzaju wypowiedzi, tzn. szerokim spectrum wykorzystywanej terminologii, obecnością zdań złożonych, wysokim stopniem stechnicyzowania itd.), należy zaznaczyć, iż rozbudowane struktury syntaktyczne zawierające słownictwo informatyczne występują w obrębie kilku zaledwie typów materiałów

${ }^{2}$ Więcej zob.: P. Jóźw i k i e w i c z, Lingua Ucraina ad res informaticas pertinens. Studium nad ukraińskim słownictwem informatycznym, Wrocław 2013, s. 18-33.

${ }^{3}$ Nazywanych przez informatyków, ale nie tylko przez nich ,helpami”; pojęcie to jest również używane w niniejszym tekście.

${ }^{4}$ Див.: Б. Рицар, Р. Мисак, Мова та термінологія зукраӥнізованих програмних продуктів фірми Майкрософт, [в:] „Вісник Національного університету «Львівська політехніка»”, № 490, Львів 2003, с. 17-24; Р. Р ожанкі в сь ки й, Інформаційна мова та інформаџійні терміни програмного продукту Ворд компанії Майкрософт [в:] Зб. наук. праць учасників 8-ї Міжнар. наук. конф. „Проблеми української термінології СловоСвіт 2004”, Львів 2004, с. 12-17; В. П. Кубайчук, Є.В.Мей нарович, До naкеmy Windows Ukrainian Interface Pack, [в:] Електронний ресурс: http://tc.terminology.lp.edu.ua/TK_sem_WinUA.htm (доступ 02.02.2012 p.); Ю.К.Онище н ко, Порівняльний термінологічний аналіз перекладів українізованих програм компанії „Майкрософт”, [в:] „Гуманітарний вісник, Серія: Іноземна філологія”, ч. 12, т. 1, Проблеми сучасної світової літератури. Проблеми сучасного перекладознавства, Черкаси 2008 , c. 220-223 чи оцінку Андрія Шевчука, редактора порталу programy.com.ua, [в:] Електронний pecypc: http://programy.com.ua/reviews/office2k3ua.php (доступ 13.08.2007р.).

${ }^{5} \mathrm{P}$. Jóźw iki ew i cz, Ukraińskie formy bezosobowe na -но/-то a język plików pomocy pakietu MS Office 2003, [w:] „Świat Słowian w języku i kulturze VIII. Językoznawstwo”, Szczecin 2007, s. 99-108; P. Jóźw i ki ew i c z, Ukraińskie rzeczowniki odczasownikowe na -нн(я), -тТ(я) a pliki pomocy programu MS Office 2003, [w:] „Świat Słowian w języku i kulturze IX Językoznawstwo. Wybrane zagadnienia z gramatyki języków słowiańskich i innych języków europejskich”, pod red. Ewy Komorowskiej i Doroty Dziadosz, Szczecin 2008, s. 80-84; P. Jóźw i kiewicz, Ukraińskie rzeczowniki odczasownikowe na -нн(я), -тт(я) - ich występowanie i funkcje syntaktyczne w tekście plików pomocy programu MS Office 2003, [w:] „Slavica Wratislaviensia CL”, Wrocław 2009, s. 83-91. 
źródłowych. Jednym z nich są właśnie pliki pomocy oprogramowania serii Microsoft Office.

Język nauk ścisłych odznacza się lakonicznością, jednoznacznością, schematowością, wyrazistością; to cechy, którymi można scharakteryzować niejeden tekst z dziedziny matematyki, fizyki, mechaniki czy, wreszcie, informatyki. Jednakże, co wydaje się bardzo ważne i co należy tu szczególnie podkreślić, rola tekstów o charakterze informatycznym sprowadza się niemal wyłącznie do zaproponowania odbiorcy pewnych rozwiązań, które dotyczą określonego zagadnienia w obszarze omawianych problemów. Owe ,propozycje” realizowane są na różne sposoby, aczkolwiek instruktażowość poszczególnych realizacji jest tu nad wyraz widoczna. W takie tło ewidentnie wpisują się pliki pomocy wspomnianych aplikacji biurowych.

Zgromadzony na potrzeby niniejszej publikacji materiał wyekscerpowano z plików pomocy zukrainizowanych komponentów pakietu Microsoft Office różnych wersji. Przytaczane poniżej przykłady są charakterystyczne dla „helpów” stanowiąc swoisty wyróżnik pośród innych struktur spotykanych w szeroko pojmowanej sferze IT.

W przeciwieństwie do nieskomplikowanej pod względem składniowym struktury np. interfejsów programowych, teksty plików pomocy charakteryzują się bogactwem konstrukcji, od zdań pojedynczych po zdania wielokrotnie złożone.

Teksty o charakterze instruktażowym, zwłaszcza teksty dotyczące sfery IT są dość specyficzne. Ich cechą charakterystyczną jest to, iż obok zdań oznajmujących informujących odbiorcę o zaistnieniu jakiegoś faktu w wirtualnym świecie, bardzo często funkcjonują w ich obrębie konstrukcje wskazujące na możliwość, potrzebę, konieczność (lub brak takowych) wykonania danej czynności. Struktury te są elementem zarówno zdań pojedynczych, jak i złożonych.

Po przeanalizowaniu wielu stron komunikatów składających się na pliki pomocy różnych wersji pakietu Office $e^{6}$ i wyodrębnieniu konstrukcji, które pojawiały się najczęściej, doszedłem do następujących wniosków:

1. Na pliki Help pakietu Office składają się (co nie może być żadnym zaskoczeniem) zdania pojedyncze dwuczłonowe $\mathrm{z}$ orzeczeniem wyrażonym formą finitywną czasownika, np.

(1) Під час кожного зберігання документа нова резервна копія заміняє наявну.

(2) Не всі типи веб-папок підтримують пошук із Microsoft Office.

(3) Панель мови міститься у правому верхньому куті екрана.

(4) Стан иьього параметра впливас на всі програми Microsoft Office.

2. Predykatywy typu можна, потрібно, слід wskazujące na hipotetyczną bądź realną możliwość zaistnienia jakiegoś faktu współtworzą orzeczenia w zdaniach pojedynczych jednoczłonowych opisywanych plików, np.

(5) Можна скористатися одночасною прокруткою обох документів для пошуку відмінностей між ними.

(6) Веб-вузол Microsoft Office Online можнна відвідувати безпосередньо із браузера.

(7) Документи Word слід перемішувати з розширенням DOC.

(8) Слід визначити позицію табуляиії з вирівнюванням за правим краєм. oraz głównie nadrzędnikach zdań złożonych, np.

(9) Можна одночасно прокручувати обидва документа, щзоб відиукувати розбіжності між ними.

${ }^{6}$ Aby uruchomić opcję przeglądu plików pomocy, należy kliknąć zakładkę Довidкa w dowolnej aplikacji pakietu Office. W przypadku braku połączenia z Internetem uruchomione zostaną zestawy podpowiedzi zawarte $\mathrm{w}$ zasobach systemowych; jeśli połączenie internetowe jest aktywne, użytkownik zostanie przekierowany na strony Microsoft Office. 
(10) У изе поле можна ввести запитання, на яке необхідно одержати відповідb.

(11) Щоб переглянути примітки та виправлення у виносках, потрібно перейти до режиму розмітки або режиму веб-документа.

(12) Потрібно обмежити термін дії дозволів на доступ для інших користувачів, але зберегти доступ для автора вмісту й після ицього терміну.

(13) Щоб автоматично створити файл відновлення, в якому макроси змінено за допомогою редактора VBE, слід якимсь чином змінити сам документ у вікні Microsoft Word.

(14) За замовчуванням Word не відображає вже використовувані сполучення клавіш, тому їх слід запам'ятати.

3. Możliwość/brak możliwości zaistnienia danego stanu, wykonania pewnych czynności przejawia się w konstrukcjach z orzeczeniem modalnym w:

- zdaniach pojedynczych dwuczłonowych, np.

(15) Помічник не може одночасно відображувати нагадування Microsoft Outlook ma nopadu.

(16) Неправильне редагування реєстру може серйозно пошкодити систему.

(17) Більшість принтерів не можуть друкувати країв аркуша.

(18) Y Microsoft Windows імена файлів можуть містити деякі розділові знаки - zdaniach złożonych, np.:

(19) Щоб ознайомитися зі своїми правами щзодо користування програмним продуктом, ви можете переглянути ліцензійну угоду Office 2003.

(20) Веб-вузол Microsoft Office Online містить багато додаткових ресурсів, які можнть допомогти в роботі з Office.

(21) Корпорація Майкрософт не може гарантувати усунення проблем, які виникли через невміле користування редактором реєстру.

(22) Якщу декілька панелей інструментів розташовуються в одному рядку, може не вистачити місия для відображення всіх кнопок.

4. Dla informatycznych tekstów instruktażowych, do których zaliczają się pliki pomocy, bardzo charakterystyczne jest również występowanie konstrukcji bezosobowych z użyciem form na -Ho, - $\mathbf{T O}^{7}$. Funkcjonowanie tego typu form w analizowanym materiale jest spowodowane faktem, iż wiele komunikatów obecnych np. w plikach pomocy odnosi się do sytuacji, w których niemożliwe jest określenie agensa, albo też ,wykonawcą” danej czynności jest program czy też jego element składowy. Obecność form bezosobowych w zdaniach pojedynczych jest raczej incydentalna, np.

(23) Використання методу або властивості заборонено параметрами безпеки.

(24) Підтримування макромови вимкнено.

(25) Далі наведено проиедуру імпорту таблииь із документа Microsoft Word do Microsoft Access. Występują one przede wszystkim w zdaniach złożonych czy wielokrotnie złożonych, np.

(26) Якщуо на комп'ютері користувача не установлено Microsoft Offiсе 2003 або пізніших версій, неможливо завантажити програму, яка дає змогу переглядати ией вміст.

(27) Ці параметри впливають на всі додатки Microsoft Office, але набирають сили в будь-якому додатку лише після того, як його перезавантажено.

(28) Коли запис макросу вимкнено, елемент ЗАП має блідий колір.

${ }^{7}$ Zob.: P. Jóźwiki ewicz, Ukraińskie formy bezosobowe na -но / -то a język plików pomocy pakietu MS Office 2003, [w:] „Świat Słowian w języku i kulturze VIII. Językoznawstwo”, Szczecin 2007, s. 99-108. 
(29) Відкриття списку, якщз його закрито, і перехід до відповідного параметра у списку ALT+ підкреслена літера в назві параметра.

(30) Переконайтеся, щзо на сервері установлено найновішу версію антивірусного програмного забезпечення.

Cechą charakterystyczną ukraińskich bezosobników jest to, że mogą one wchodzić w relacje $\mathrm{z}$ formami finitywnymi czasownika бymu, wskazując tym samym na możliwość zaistnienia danej czynności w przyszłości bądź potwierdzając, iż dana czynność miała miejsce w przeszłości. Tak jak ma to miejsce w wypadku „autonomicznych" form bezosobników, tu także nieznany jest wykonawca czynności. Formy te $\mathrm{w}$ analizowanym materiale występowały niemal wyłącznie w zdaniach polipredykatywnych, np.

(31) Перед втратою файлу було ввімкнено режим автовідновлення, але зберегти або відкрити відновлений файл не вдається.

(32) Якщо було виділено непотрібний файл, клащчніть його щзе раз, утримуючи клавішу CTRL.

(33) Після подвійного клацуання цฺього значка буфер обміну Microsoft Office буде відкрито в активному додатку.

(34) Перейменуйте всі файли, які буде знайдено.

(35) Якщз призначити сполучення клавіш CTRL +B новій команді або іншому елементу, то їх початкове застосування стане неможливим доти, поки не буде відновлено початкове призначення цьього сполучення клавіш.

Wśród analizowanego materiału incydentalnie występowały również zdania, w których bezosobowość wyrażana była jednocześnie formami przeszłymi, jak i przyszłymi, np. w zdaniu:

(36) Однак пароль, який було використано для цьього захисту, буде втрачено.

W języku ukraińskim formy bezosobowe na -но, -то wchodzą w skład orzeczeń, których elementem są czasowniki modalne. Struktury tego typu występują również w zebranym materiale faktograficznym, np.

(37) Під час форматування гіперпосилань може бути відформатовано навіть ті гіперпосилання, адреси URL яких містять пробіли.

(38) Для правильного відображення uуих документів у раніших версіях Мicrosoft Word форматування, яке не підтримується цүими версіями, може бути замінено на таке, шзо підтримується.

(39) Щоб панель Мої адреси відобразилася у вікні Вставка малюнка, має бути відкрито повідомлення.

(40) Щоб вставити фільм у документ Microsoft Word, на комп'ютері має бути установлено програму відтворювання фільмів, наприклад, Media Player-додаток Microsoft Windows, щуо надає змогу відтворювати звук, відео та анімацію, а комп 'ютер повинно бути обладнано звуковою картою.

5. Do niezwykle charakterystycznych konstrukcji, będących niejako wykładnikiem dla tekstów instruujących odbiorcę w danej kwestii czy skłaniających go do wykonania określonych czynności zaliczyć należy zdania celowe i warunkowe, w których centra zdań nadrzędnych stanowią czasowniki w formie trybu rozkazującego, np.

- zdania celowe:

(41) Щоб обмежити область пошуку, скористайтеся розкривним списком Пошук в області завдань Результати пошуку.

(42) Щоб переглянути пораду, клацніть цюю лампочку.

(43) У меню Довідка виберіть команду Довідка Microsoft <назва програми>, щчоб відобразити область завдань Довідка <назва програми>. 
(44) Щоб перевірити параметри відображення вмісту з мережі, виконайме такі діï.

(45) Щоб змінити інтервал автозбереження, введіть число в поле хвилин на вкладиі Збереження діалогового вікна Параметри (меню Сервіс).

- zdania warunkowe:

(46) Якщзо папку або шаблон не вдається знайти, знову запустіть програму установки.

(47) Якщо меню Сервіс вже містить команду Надбудови для моделі СОМ, перейдіть до кроку 6.

(48) Якщчо потрібно відформатувати дискету, вставте ї̈ в дисковод.

(49) Якщо отримати доступ до сервера мережі все ще неможливо, зверніться до адміністратора мережі.

(50) Якщуо файл неможливо зберегти в іншому місиі, видаліть із диска непотрібні файли або додайте на комп 'ютер інший диск.

Zdecydowanie rzadziej napotkać można zdania warunkowe, w których orzeczenie w zdaniach nadrzędnych występowałoby w innej formie — bezosobników, form finitywnych, predykatywów, form modalnych, imiennych itd., np.

(51) Миттєве повідомлення можна надіслати будь-якому користувачеві, якщу його смарт-тег «Імена» не показує автономний стан.

(52) Якщо відкрити буфер обміну Microsoft Office в області задач одного додатка Microsoft Office, його не буде автоматично відображено у разі переходу в інший додаток Мicrosoft Office.

(53) Якщо після відкриття файлу відновлення його не зберегти, то він видалясться з втратою усіх незбережених змін.

(54) Якщо значення недопустиме для умови або властивості, кнопка Додати буде недоступна.

(55) Якщзо вибрати файл Microsoft Excel у списку об'єктів у діалоговому вікні Відкриття документа в Microsoft Word, Microsoft Office намагатиметься відкрити його у Word.

(56) Якщо вікно програми не розгорнуте на весь екран, деякі кнопки панелі інструментів можсть бути приховані.

(57) Якщу під час роботи мікрофон буде випадково зрушено, його слід повернути до правильного положення.

6. Jednym z wyróżników tekstów z dziedziny IT jest obecność form nakazowych wchodzących w skład zdań wielokrotnie złożonych, np.

(58) Переконайтеся, щз ви працюєте в компоненті, який дає змогу розробляти програми.

(59) Виберіть Visual Basic для додатків, клацніть стрілку напроти, а потім виберіть варіант Запускати з мого комп 'ютера.

(60) Почніть з роботи в тихому довкіллі, щуоб комп'ютер сприймав ваме мовлення, а не сторонні звуки, та використовуйте високоякісний мікрофон блиюньої дії.

(61) У діалоговому вікні Параметри служб перевірте, чи установлено прапорець Показати вміст і посилання з веб-вузла Microsoft Office Online, ma установіть прапориі для потрібного додаткового вмісту з мережі.

(62) У меню Формат виберіть команду, щзо відповідає типу виділеного об'єкта, наприклад, Автофігура, Полотно або Малюнок, а потім відкрийте вкладку Розташування.

7. Do elementów wyróżniających badany materiał faktograficzny należą także zdania pytające, których funkcje nie ograniczają się jedynie do wprowadzenia ko- 
lejnych partii tekstu, to również tytuły poszczególnych podrozdziałów omawianego materiału. Z punktu widzenia komunikacji są one bezpośrednim zwrotem do odbiorcy, częścią składową swoistego dialogu na linii komputer - użytkownik, np.

(63) Що може робити ия програма?

(64) Чому й коли слід використовувати ию програму?

(65) Для чого може знадобитися Microsoft Office Document Imaging?

(66) Чи були иі відомості корисні?

(67) Що ви бажсаєте зробити?

(68) Вам потрібна допомога, або ви маєте пропозииії щодо продукту?

(69) Маєте запитання стосовно Office?

(70) Вам потрібні поради досвідчених користувачів або розробників?

(71) То ж які нові функції товариств Оffice могли б зробити изі групи ще кориснішими для вас?

(72) Чи допомогла ия відповідь розв'язати проблему?

Warto dodać, że temu szczególnemu sposobowi „komunikowania się” programu z odbiorca, stwarzaniu wrażenia kontaktu bezpośredniego, udzielaniu „dobrych rad” towarzyszy częste występowanie form grzecznościowych i specyficzna, dostosowana do takiej sytuacji budowa zdań, np.

(73) Якщзо на всі иі запитання ви даєте ствердну відповідь, вам сюди - подивіться, що можуть запропонувати товариства Оffice.

(74) Пакет Microsoft ${ }^{\circledR}$ Office System містить області завдань, які дадуть вам змогу розв'язати ичі проблеми.

(75) Не забудьте зареєструватися, щоб участь у товаристві була зручнішою для вас.

(76) Ви заощадите багато часу, якщо виберете додаток, спеціально пристосований до завдань, які вам потрібно виконати.

(77) То ж які нові функції товариств Оffice могли б зробити изі групи ще кориснішими для вас?

(78) Якщо змінений спосіб запускання ви плануєте використовувати часто, можна створити відповідний ярлик на робочому столі Microsoft Windows.

(79) Програми такого класу сполучають між собою два світи - інформацію на електронних носіях і на папері, завдяки чому ви можете підвищити продуктивність своєї праиі.

(80) Працюючи в інтерактивному режимі (з підключенням до Інтернету), ви маєте доступ до всіх розділів довідки, шаблонів, навчальних курсів, статей і графіки, наявних на вузлі Microsoft Office Online безпосередньо в Microsoft Office.

(81) Проте, Windows XP не підтримує копіювання на DVD, тому вам потрібно скористатися авторською програмою для DVD.

Pliki pomocy serii aplikacji biurowych Microsoft Office są charakterystyczne pod wieloma względami. To nie tylko jedna z najbardziej rozbudowanych z punktu widzenia prezentowanych informacji struktur tekstowych w tego typu oprogramowaniu; to również tekst tłumaczony na wiele języków świata, w tym, od nieco dłużej niż dekady, na język ukraiński.

Na marginesie należy podkreślić, że ukraińskie tłumaczenia „helpów” nie są wolne od błędów. Stwierdzenie to dotyczy szczególnie pierwszych przekładów opisywanych struktur. Kwestia ich poprawności była podnoszona nie tylko przez językoznawców, ale również użytkowników, którzy niejednokrotnie we własnym zakresie podejmowali się roli thumaczy ${ }^{8}$.

\footnotetext{
${ }^{8}$ Zob. m. in.: Żródło elektroniczne: http://domivka.net/ukrainizatsiia pz/ (odczyt: 27.12.2014 r.).
} 
Struktura składniowa ukraińskiej wersji plików pomocy aplikacji Microsoft Office niewątpliwe odróżnia się od innych typów tekstów z dziedziny informatyki. Wśród cech wybijających się na pierwszy plan należałoby wymienić te, które opisano w niniejszym tekście, a więc obecność zdań współtworzonych przez predykatywy typu можна, потрібно, слід, orzeczenia modalne, bezosobniki na -но, -то, w tym ich formy złożone (було ввімкнено, буде втрачено, має бути установлено, повинно бути обладнано). Nie można naturalnie pominąć konstrukcji, które pojawiają się niezwykle często - zdań celowych i warunkowych, zwłaszcza tych, w których centrum nadrzędnika stanowią formy rozkazujące czasownika. Pliki pomocy wyróżniają się również mnogością zdań wielokrotnie złożonych (wielu z formami rozkazującymi), zdań pytających oraz konstrukcji, w których obecne są zwroty grzecznościowe wspomagane odpowiednią leksyką i formami gramatycznymi (не забудыте зареєструватися; дадуть вам змогу; вам потрібно скористатися itd.).

Pliki pomocy oprogramowania biurowego serii Microsoft Office epatują wręcz strukturami specyficznymi dla tekstów informatycznych. Omówione w proponowanym artykule konstrukcje stanowią część z nich, zaś samo źródło ze względu na swe znaczenie i rolę, jaką pełni, warte jest dalszych badań, nie tylko w zakresie składni języka ukraińskiego. 